\title{
HIV-1 splicing is modulated by RNA structure
}

\author{
Nancy Müller*, Alex Harwig, Ben Berkhout, Atze T Das \\ From Frontiers of Retrovirology 2011 \\ Amsterdam, The Netherlands. 3-5 October 2011
}

\section{Background}

HIV-1 is a retrovirus with a $\sim 9 \mathrm{~kb}$ RNA genome that contains 9 open reading frames and untranslated leader and tail regions. The full length RNA is used as genomic RNA that is packaged in the virion and as mRNA for translation of the Gag and Pol proteins. More than 40 differently spliced RNAs are produced that encode the other viral proteins. Splicing has to be strictly regulated in order to obtain the right balance between unspliced and spliced RNAs at the different phases of the viral life cycle. The 5'leader RNA encodes the major splice donor (SD) sequence that is used for the production of all spliced HIV-1 RNAs. This SD region can fold a stemloop structure and the stability of this hairpin may be instrumental for the regulation of splicing by restricting the accessibility for the splicing machinery. In order to test this hypothesis, we varied the thermodynamic stability of the SD stem-loop through mutation and analysed the effects on virus replication and HIV-1 RNA splicing.

\section{Materials and methods}

The SD stem-loop structure in the HIV-1 leader RNA region was stabilized or destabilized through mutation in the context of the HIV-1 molecular clone pLAI. The effect of the SD hairpin mutation on viral gene expression was measured upon transfection of $293 \mathrm{~T}$ cells and virus replication was measured upon infection of SupT1 cells. The mutations were also introduced into an LTRluciferase reporter plasmid that was designed to monitor SD splicing by causing reduced luciferase activity. Upon transfection of these constructs into $293 \mathrm{~T}$ cells, the efficiency of splicing at the major SD site was analysed by luciferase activity assays and RNA analysis (RT-PCR).

Laboratory of Experimental Virology, Department of Medical Microbiology, Center for Infection and Immunity Amsterdam (CINIMA), Academic Medical Center of the University of Amsterdam, Meibergdreef 15, 1105 AZ

Amsterdam, The Netherlands

\section{Results}

Further stabilization of the SD stem-loop structure significantly reduced HIV-1 gene expression and replication and splicing was inhibited in the LTR-luciferase assay. SD hairpin destabilization did not cause major virus replication effects, but LTR-luciferase experiments revealed a modest upregulation of the splicing efficiency.

\section{Conclusions}

The stability of the SD stem-loop structure modulates the frequency of splicing at the major SD site. These results suggest that the stability of this hairpin is finetuned to obtain the right balance between unspliced and spliced RNAs in HIV-infected cells.

Published: 3 October 2011

doi:10.1186/1742-4690-8-S2-P52

Cite this article as: Müller et al:: HIV-1 splicing is modulated by RNA structure. Retrovirology 2011 8(Suppl 2):P52.

Submit your next manuscript to BioMed Central and take full advantage of:

- Convenient online submission

- Thorough peer review

- No space constraints or color figure charges

- Immediate publication on acceptance

- Inclusion in PubMed, CAS, Scopus and Google Scholar

- Research which is freely available for redistribution 